\title{
Regional Enhancement Center
}

National Cancer Institute

\section{Source}

National Cancer Institute. Regional Enhancement Center. NCI Thesaurus. Code C19976.

Mechanism to facilitate partnerships between $\mathrm{NCl}$-Designated Comprehensive Cancer

Centers and research institutions to provide patients and populations with improved access to studies. 